\title{
ADMINISTRATIVNE PREPREKE S KOJIMA SE SUOČAVAJU MALA I SREDNJA PODUZEĆA NA PODRUČJU ZAPOŠLJAVANJA
}

Mala i srednja poduzeća imaju ključnu ulogu u europskom gospodarstvu, ali istovremeno su suočena s mnogo većim administrativnim poteškoćama u svojem poslovanju u usporedbi s velikima. Postojeća rigidnost na tržištu rada još više je otežala njihov položaj prilikom kreiranja novih radnih mjesta. Upravo stoga cilj ovog rada bio je provjeriti postoje li između različitih grupa malih $i$ srednjih poduzeća značajne razlike $u$ opterećenosti administrativnim poslovima na području zapošljavanja? Rezultati istraživanja pokazuju kako Hrvatska u usporedbi s drugim zemljama Europske unije (EU) još uvijek obiluje rigidnostima i ima relativno strogo tržište rada. Primarno istraživanje provedeno u Hrvatskoj obuhvatilo je konačni uzorak od $701 \mathrm{ma-}$ log i srednjeg poduzeća. Rezultati istraživanja pokazali su da većina malih $i$ srednjih poduzeća (54\%) najvećom administrativnom preprekom na području regulacije tržišta rada smatra prečeste izmjene propisa vezane uz poslovanje. Na temelju provedenog istraživanja zaključeno je da postoje značajne razlike između različitih grupa (broj zaposlenih, pravno-organizacijski oblik i sektor) malih i srednjih poduzeća u pogledu broja ključnih administrativnih prepreka na području zapošljavanja, koje najviše percipiraju mikro poduzeća i obrtnici koji razvijaju svoju djelatnost u području tercijarnog sektora.

Ključne riječi: administrativne prepreke, mala i srednja poduzeća, tržište rada, $E U, R H$

* Dr. sc. A. Obadić, redovita profesorica, Sveučilište u Zagrebu, Ekonomski fakultet Zagreb (E-mail: aobadic@efzg.hr).

Rad je primljen u uredništvo 13.12.2017. godine, a prihvaćen je za objavu 30.01.2018. 


\section{Uvod}

Na području Europe, mala i srednja poduzeća danas imaju ključnu ulogu u gospodarstvima pojedinih nacionalnih ekonomija. U usporedbi sa velikim poduzećima, često se susreću s brojnim poteškoćama (unutarnjim, administrativnim i financijskim), koje ih nerazmjerno pogađaju. To je i razlog što često imaju i lošije učinke, koji se očituju u nižoj profitabilnosti, nižoj stopi preživljavanja, većim fluktuacijama radnika i dr. Mala i srednja poduzeća danas čine $99 \%$ svih kompanija na području EU. Osiguravaju dvije trećine poslova privatnog sektora te doprinose više od polovice ukupne dodane vrijednosti koja su stvorila sva poduzeća (European Parliament, 2017., str. 1). Većina malih i srednjih poduzeća u EU djeluje na nacionalnoj razini, ali su pod utjecajem europske legislative u različitim područjima, kao što je oporezivanje, konkurentnost i pravo trgovačkih društava. Cilj politika EU za mala i srednja poduzeća je osiguravanje odgovarajućih i aktivnosti, koje su poslovno prihvatljive te stvaranje Europe privlačnijim mjestom za uspostavljanje poduzeća i vođenje poslovanja (European Parliament, 2017., str. 1). Mala i srednja poduzeća imaju ključnu ulogu i u hrvatskom gospodarstvu obzirom da zapošljavaju dvije trećine ukupno zaposlenih.

Obzirom na prethodno istaknutu važnost malih i srednjih poduzeća za ekonomski rast svakog gospodarstva, u radu se istražuje utjecaj administrativnih prepreka na području regulacije tržišta rada. Naime, mala i srednja poduzeća često ističu kako administrativne i regulatorne prepreke predstavljaju značajan teret njihovog rasta i smanjenja konkurentnosti. Stoga je tema smanjivanja administrativnih prepreka poslovanja postala sve važnija tema kreatora ekonomskih politika. Troškovi za manja poduzeća su mnogo veći u usporedbi s velikima u smislu poštivanja svih odredbi i propisa te ih nekoliko zemalja članica aktivno potpomaže kada se radi o poreznim odredbama ili uzimaju u obzir njihove specifične karakteristike prilikom izrade nacrta zakona. Europski parlament je dugogodišnji pobornik povoljnog okruženja za mala i srednja poduzeća koje pridonosi rastu. Ekonomska literatura ističe kako se mala i srednja poduzeća suočavaju s brojnim preprekama prije svega zbog svoje veličine (Szczepaǹski, 2016.). Uklanjanje administrativnog tereta i prepreka predstavlja središnje pitanje koje je potrebno riješiti kako bi se poboljšala poslovna klima i konkurentnost, olakšao razvoj i povećalo stvaranje novih radnih mjesta.

Stoga se osnovni cilj ovoga rada odnosi na utvrđivanje postojećeg stanja i odnosa krutosti na tržištu rada EU-28 i Hrvatske. Nadalje cilj je i ocijeniti trenutno stanje administrativnih prepreka malih i srednjih poduzeća na području regulacije tržišta rada u Hrvatskoj. U skladu s navedenim ciljem rada postavljeno je i glavno istraživačko pitanje rada: odrediti postoje li između različitih grupa malih i srednjih poduzeća (s obzirom na broj zaposlenih, pravno-organizacijski oblik i 
sektor) značajne razlike u opterećenosti različitih skupina malih i srednjih poduzeća administrativnim poslovima na području zapošljavanja? Na temelju navedenog proizlazi i glavna hipoteza istraživanja: između različitih grupa malih i srednjih poduzeća (s obzirom na broj zaposlenih, pravno-organizacijski oblik i sektor) postoje značajne razlike u broju ključnih administrativnih prepreka na području zapošljavanja.

Rad je podijeljen u pet poglavlja. Nakon uvoda, u drugom dijelu slijedi teorijski okvir i pregled literature čija je svrha ukazati na važnost i snagu malih i srednjih poduzeća u EU te definirati administrativne prepreke, posebno one na tržištu rada, s kojima se susreću. U trećem dijelu slijedi opis metodologije, dok su u četvrtom dijelu prikazani rezultati istraživanja i diskusija. Rad završava zaključkom.

\section{Teorijski okvir i pregled literature}

Teorijska analiza u ovom dijelu rada rezultat je iscrpnog pregleda literature koji započinje temeljnim definicijama malih i srednjih poduzeća u kontekstu značaja njihove gospodarske snage u nacionalnim ekonomijama. U nastavku slijedi analiza stanja i strukture malih i srednjih poduzeća na području EU-28 te teorijski pregled administrativnih prepreka koji se koristi za daljnje razumijevanje prepreka indikatora krutosti na tržištu rada.

\subsection{Značaj malih i srednjih poduzeća u Europskoj uniji}

Mala i srednja poduzeća se većinom definiraju prema broju zaposlenih osoba, ukupno ostvarenom prihodu ili izvozu, iako se definicije razlikuju među zemljama i institucijama. Kao što ističe Hyman, najčešći kriterij koji se koristi je broj zaposlenih (Hyman, 1989., str. 199). Granice broja zaposlenih za pojedine veličine poduzeća razlikuju se među nacionalnim statističkim sustavima. Tako neke zemlje postavljaju granicu na 200 zaposlenih, dok Sjedinjene američke države u mala i srednja poduzeća uključuju poduzeća s manje od 500 zaposlenih. Mala poduzeća su općenito ona koja imaju manje od 50 zaposlenih, dok mikro poduzeća imaju najviše do deset, ili u nekim slučajevima, pet zaposlenih (OECD, 2000., str. 2). Kao najčešća gornja granica za broj zaposlenih u malim i srednjim poduzećima na području zemalja EU koristi se 250 (European Commission, 2003.). Tako se definicija veličine poduzeća koja se koristi u ovom radu temelji na definicijama koje koristi statistički ured Europske komisije (Eurostat) u svojim Strukturnim 
poslovnim statistikama (engl. Structural Business Statistics, SBS). Ona se prvenstveno temelji na broju zaposlenih osoba, ali ujedno definira mala i srednja poduzeća kao poslovanje sa manje od 250 zaposlenih, godišnjim prometom manjim od 50 milijuna eura te ukupnom bilancom manjom od 43 milijuna eura (European Commission, 2003.). U tablici 1 prikazana je najčešće korištena podjela malih i srednjih poduzeća u okviru koje je moguće razlikovati tri veličine poduzeća: mikro, malo i srednje poduzeće.

Tablica 1 .

DEFINICIJA VELIČINE MALIH I SREDNJIH PODUZEĆA NA PODRUČJU EU

\begin{tabular}{|l|c|c|c|}
\hline Kategorija poduzeća & Zaposlenici & Promet & Ukupna bilanca \\
\hline Mikro & $<10$ & $<2$ milijuna EUR & $<2$ milijuna EUR \\
\hline Malo & $<50$ & $<10$ milijuna EUR & $<10$ milijuna EUR \\
\hline Srednje & $<250$ & $<50$ milijuna EUR & $<43$ milijuna EUR \\
\hline
\end{tabular}

Izvor: European Commission (2016.a, str. 3).

Zahvaljujući snažnom gospodarskom rastu u posljednje dvije godine, razina dodane vrijednosti malih i srednjih poduzeća na području EU-28 bila je gotovo 9\% veća nego u 2008. godini (European Commission, 2016., str. 1). Bez obzira na njihovu značajno veću fleksibilnost u pogledu stvaranja novih radnih mjesta u odnosu na velika poduzeća (Obadić, Aristovnik, 2016.), razina zaposlenosti je još uvijek ispod razine iz 2008. godine. Mala i srednja poduzeća čine okosnicu europskog gospodarstva. U 2015. godini nešto manje od 23 milijuna malih i srednjih poduzeća na području EU-28 stvorilo je 3,9 trilijuna dodane vrijednosti (3/5 ukupne dodane vrijednosti) i zapošljava 90 milijuna ljudi (2/3 svih zaposlenih), (European Commission, 2016., str. 1). Veličina stvarnog rasta dodane vrijednosti i zapošljavanja razlikuje se među zemljama članicama, a porast zapošljavanja u malim i srednjim poduzećima posljedica je rasta broja poduzeća, a ne novog zapošljavanja obzirom da je broj zaposlenih u malim i srednjim poduzećima ostao stabilan u 2014. i 2015. godini. 
Tablica 2.

STRUKTURA PODUZEĆA U EU-28 I HRVATSKOJ S OBZIROM NA BROJ ZAPOSLENIH I UKUPAN PRIHOD (U \%), 2015. GODINI

\begin{tabular}{|l|c|c|c|c|}
\hline \multirow{2}{*}{ Kategorija poduzeća } & \multicolumn{2}{|c|}{ EU-28 } & \multicolumn{2}{c|}{ Hrvatska } \\
\cline { 2 - 5 } & $\begin{array}{c}\text { Ukupan } \\
\text { prihod }\end{array}$ & Zaposlenost & $\begin{array}{c}\text { Dodana } \\
\text { vrijednost }\end{array}$ & Zaposlenost \\
\hline Mikro & 21,20 & 29,5 & - & - \\
\hline Malo & 18,00 & 20,2 & $35,4^{*}$ & $51,6^{*}$ \\
\hline Srednje & 18,20 & 17,0 & 18,6 & 17,6 \\
\hline Mala i srednja - ukupno & 57,40 & 66,8 & 54,0 & 69,2 \\
\hline Velika & 42,60 & 33,20 & 46,0 & 30,8 \\
\hline
\end{tabular}

Izvor: European Commission (2016.a) i CEPOR (2017.).

Napomena: * za Hrvatsku ne postoje odvojeni podaci za mikro i mala poduzeća.

Prema podacima u Tablici 2, u Hrvatskoj je u 2015. godini poslovalo 106.221 mikro, malih i srednjih poduzeća (99,7\% ukupno registriranih poduzeća), koja ostvaruju udio od 54\% u ukupnom prihodu, 69,2\% u zaposlenosti i 50,3\% u izvozu Hrvatske (CEPOR, 2017., str. 7). U 2015. godini udio malih i srednjih poduzeća u ukupnom prihodu iznosio je 54\% što je neznatno povećanje (oko $1 \%$ bod) u odnosu na 2014. godinu. Međutim, promjene u prihodima ovisno o veličini poduzeća su znatno uočljivije. Tako je ukupan prihod malih poduzeća u 2015. godini porastao je za $4,8 \%$, srednjih poduzeća za $6 \%$, a velikih poduzeća za $1,3 \%$ u odnosu na 2014. godinu (CEPOR, 2017., str. 12). Mala poduzeća, iako imaju najveći udio u zaposlenosti $(51,6 \%)$ u strukturi ukupnog prihoda sudjeluju s $35,4 \%$. Srednja poduzeća imaju podjednak udio u zaposlenosti i ukupnom prihodu (CEPOR, 2017, str. 13).

U usporedbi s velikim poduzećima, mala i srednja poduzeća često stvaraju nešto slabije rezultate, kao što su niža profitabilnost, veća fluktuacija zaposlenika, niža stopa preživljavanja, manje uspjeha u području inovacija, manji kapacitet za ulaganje u razvoj i usavršavanje zaposlenika i drugo (Szczepaǹski, 2016., str. 2). Navedeno se može djelomično objasniti postojanjem značajnih prepreka ulasku novih zaposlenika i rastu, koji je svojstven većini ekonomija. Manja poduzeća suočavaju se s nerazmjerno većim regulatornim opterećenjem od većih poduzeća (Aristovnik, Obadić, 2015., str. 765), a neučinkovita javna uprava, slaba pravosudna sposobnost i pravna nesigurnost i dalje su glavna prepreka industrijskoj konkurentnosti i gospodarskom rastu u članicama EU (European Commission, 2014., str. 52) 


\subsection{Administrativne prepreke}

Administrativne prepreke predstavljaju skupni naziv za administrativno opterećenje, koje treba razlikovati od administrativnog tereta. Naime, administrativne prepreke predstavljaju sve što neopravdano otežava poslovanje poduzeća, za razliku od administrativnog tereta koji se može šire definirati kao svi troškovi koji proizlaze iz prinudnih obveza koje posjeduju javne vlasti na temelju zakona, odredbi ili sličnih akata (Szczepaǹski, 2016., str. 6). Administrativni tereti razlikuju se među europskim zemljama, a uključuju: (a) europski zakon i domaće pravne akte potrebne za njegovo usklađivanje sa nacionalnim zakonom, (b) računovodstvene i porezne zahtjeve, kao i (c) sektorske i industrijski specifične zakone i obveze izvješćivanja i usklađenosti (Szczepaǹski, 2016., str. 6). Administrativne prepreke predstavljaju troškove poduzećima i građanima u ispunjavanju temeljnih obveza koje proizlaze iz vladinih zakona i propisa (European Commission, 2014.). Mogu se definirati kao (ponavljajući) troškovi administrativnih aktivnosti koje su poduzeća dužna obavljati kako bi se pridržavale obaveza koje su im nametnute putem regulacije središnje države (UK Cabinet Office, 2006.).

Nametanje često prestrogih regulatornih obveza za mala i srednja poduzeća, navelo je Europsku komisiju da uvede posebne akcijske planove za pojednostavljivanje i poboljšanje regulatornog okruženja. Glavni pokretači koji stoje iza programa „Bolja regulacija za rast i poslove u Europskoj uniji“ (engl. „Better Regulation Programs"), pretpostavljaju kako bi jače usmjerenje na smanjivanje administrativnog opterećenja poduzeća dovelo do boljih politika, bolje provedbe, bolje usklađenosti i naposljetku, bolje vlade (UK Cabinet Office, 2006.). U dokumentu COM (2005) 97 „Bolja regulacija za rast i poslove u Europskoj uniji“, Komisija ohrabruje zemlje članice da nastave samostalno nadalje razvijati poboljšane administrativne propise (European Commission, 2005.). U okviru Lisabonske strategije, Europska komisija je pokrenula svoj program "Bolja regulacija". Kako bi se navedena strategija usvojila do početka 2007. godine, Komisija je usvojila „Akcijski program za smanjenje administrativnih troškova u EU“. Akcijski plan je odobrilo Europsko vijeće koje je naglasilo postavljanje cilja za smanjenje administrativnih tereta za 25\% do 2012. godine. Takvo smanjenje moglo bi dovesti do povećanja BDP-a EU od 1,4\% (European Commission, 2007.).

Kao što ističe Szczepaǹski, ekonomska literatura široko klasificira prepreke rastu malih i srednjih poduzeća u tri osnovne kategorije: unutarnje (npr., nedovoljne vještine i resursi na razini poduzeća), administrativne (npr., porezni sustavi, složeni zakoni) i financijske (većinom pristup financiranju), (Szczepaǹski, 2016., str. 2). Posljednje sveobuhvatno istraživanje Eurobarometra, iz 2007. godine, prije krize koje je bilo usmjereno na specifične poteškoće malih i srednjih poduzeća 
pokazalo je da su najveći problemi bili: strogi administrativni propisi, niska dostupnost i trošak odgovarajućih ljudskih resursa (gotovo trećina poduzeća je tvrdila da se suočava s poteškoćama u tom području), nedovoljna infrastruktura i ograničeni pristup financiranju (više od $20 \%$ poduzeća se suočava sa poteškoćama u tom području), (Szczepaǹski, 2016., str. 2). Činjenice pokazuju da mala i srednja poduzeća snose nesrazmjerno veća regulacijska i administrativna opterećenja u usporedbi s velikim poduzećima.

Szczepaǹski (2017.) zaključuje kako razne studije pokazuju da je za manje subjekte trošak usklađenosti s regulatornim opterećenjima i zahtjevima nerazmjerno visok. Ukupni trošak administrativnog opterećenja kao udio u BDP-u razlikuje se među članicama EU. Italija, Španjolska, Poljska, Grčka i Mađarska bilježe najveće razine (između 4,6 i 6,8\% BDP-a), dok Finska, Švedska, Ujedinjeno kraljevstvo, Danska i Irska bilježe najniže razine (između 1,5\% i 2,4\% BDP-a), (Szczepaǹski, 2017., str. 13). Opterećenje malih i srednjih poduzeća je veliko zbog čestih pogrešaka, koje ne uzimaju u obzir posebna obilježja malih gospodarstva prilikom oblikovanja zakona, ali i zbog same prirode administrativnog tereta. Dužnosti i obveze su često identične za manja i veća poduzeća, ali mala i srednja poduzeća su manje efikasna u rješavanju propisa (npr., ona investiraju manje u IT sustave za podršku, a i u manjim poduzećima sami poduzetnici troše dragocjeno vrijeme na rješavanje usklađenosti i izvješćivanja (Szczepaǹski, 2017., str. 13). Stručnjaci procjenjuju da dok velika poduzeća plaćaju 1 EUR po zaposleniku za regulatorne obveze, mala poduzeća za iste troškove plaćaju do 10 EUR. Studije pokazuju kako se poduzeća s manje od deset zaposlenika moraju suočiti s regulatornim opterećenjem (mjereno po zaposleniku), koje je gotovo dvostruko veće od opterećenja poduzeća koje ima više od 10, a manje od 20 zaposlenika i gotovo tri puta veće od opterećenja poduzeća koje ima više od 20, a manje od 50 zaposlenika (Szczepaǹski, 2016., str. 7). Za velika poduzeća, opterećenje po zaposleniku čini svega jednu petinu ili manje u usporedbi sa malim poduzećima. Neravnopravno regulatorno opterećenje postoji zbog nekoliko razloga, kao što su: (i) usklađenost s propisima ima karakteristike fiksnih troškova (npr. dužnosti o informiranju su iste za mala i velika poduzeća), (ii) mala i srednja poduzeća su manje efikasna u bavljenju s propisima (npr., ona investiraju manje u specifičnu kompjuterizaciju) i (iii) često su sami poduzetnici ti koji se moraju baviti regulacijom i propisima (Szczepaǹski, 2016., str. 7).

Europski parlament već godinama u svojim rezolucijama ističe kako su specifične prepreke s kojima se suočavaju mala i srednja poduzeća posljedica njihove male veličine (Szczepaǹski, 2017.). Od 2011. godine kontinuirano ističe kako je smanjivanje administrativnih barijera, bolji pristup financijskim prilikama i podrška kreiranju konkurentskog okruženja ključno pitanje kako bi se omogućio uspješan poslovni razvoj i kreiranje novih radnih mjesta (European Parliament, 
2017., str. 4). Europska komisija i Europska središnja banka provode zajednička1 godišnja istraživanja o pristupu financiranja poduzeća te ujedno prate najkritičnije probleme na koje ukazuju mala i srednja poduzeća. Među šest najvećih problema koja su poduzeća identificirala u razdoblju od 2011.-2016. su pronalaženje kupaca, dostupnost stručnog osoblja i menadžera, konkurencija, regulacija, troškovi proizvodnje ili rada i pristup financiranju, a prikazani su u grafikonu 1.

\section{Grafikon 1.}

\section{NAJVEĆI PROBLEMI S KOJIMA SE SUOČAVAJU MALA I SREDNJA PODUZEĆA NA PODRUČJU EU-28, 2011.-2016. GODINE}

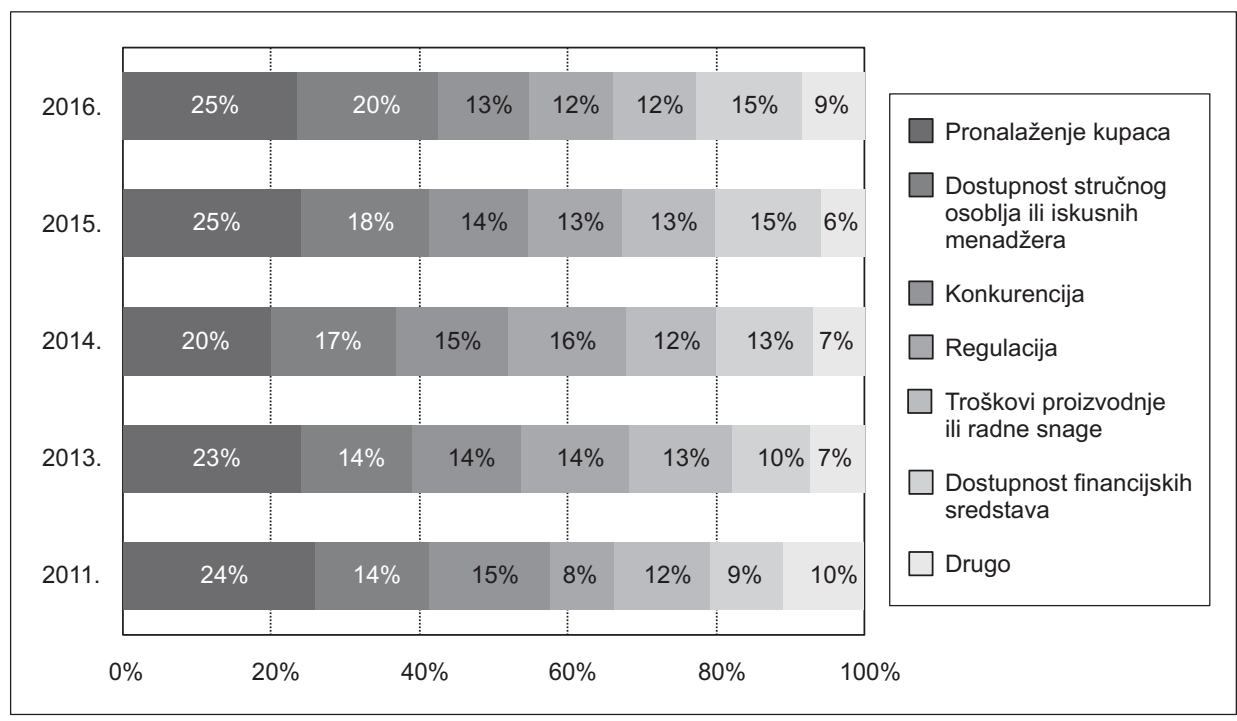

Izvor: European Commission (2016.b.).

Od svih navedenih problema, mala i srednja poduzeća tijekom cijelog promatranog razdoblja kao najveći problem ističu pronalaženje kupaca za svoje proizvode ili usluge. Navedeno rangiranje problema provodi se na osnovu ocjene ispitanika koji su zamoljeni da na skali od 1 do10 pridruže određenom problemu broj u skla-

1 Više o zajedničkom istraživanju pod nazivom Anketa o pristupu financiranju poduzeća (engl. Survey on the Access to Finance of Enterprises - SAFE) vidjeti u službenom pismu Europske komisije i Europske središnje banke - https://www.ecb.europa.eu/stats/money/surveys/sme/shared/ pdf/EN_SAFE_introductory_letter.pdf (15.10.2017.) 
du s intenzitetom problema kako ga oni doživljavaju. U 2016. je čak 25\% malih i srednjih poduzeća problem pronalaska kupaca smatralo najvažnijim problemom. Mala i srednja poduzeća u EU ovisna su prvenstveno o domaćem tržištu čija razina potražnje se još uvijek nije vratila na pred-kriznu razinu. Kao slijedeći važan problem ističe se pronalaženje stručnog osoblja ili menadžera sa iskustvom (20\%), dok trećim i četvrtim problemom po važnosti smatraju konkurenciju (13\%) i regulaciju (12\%). Pod regulacijom se podrazumijevaju europski i nacionalni zakoni te industrijski propisi, koji opterećuju administrativno poslovanje malih i srednjih poduzeća. Navedeni pokazatelj smatran je u 2011. godini najvećim problemom samo u $8 \%$ slučajeva, dok je uz određene varijacije od 2011. do 2015. godine u 2016. godini činio najveći problem u 12\% malih i srednjih poduzeća.

Na grafikonu 2. prikazani su najveći problemi s kojima se suočavaju mala i srednja poduzeća na području EU-28 i izdvojeno u Hrvatskoj tijekom 2016. godine.

\section{Grafikon 2.}

\section{NAJVEĆI PROBLEMI S KOJIMA SE SUOČAVAJU MALA I SREDNJA PODUZEĆA NA PODRUČJU EU-28 I RH U 2016. GODINI}

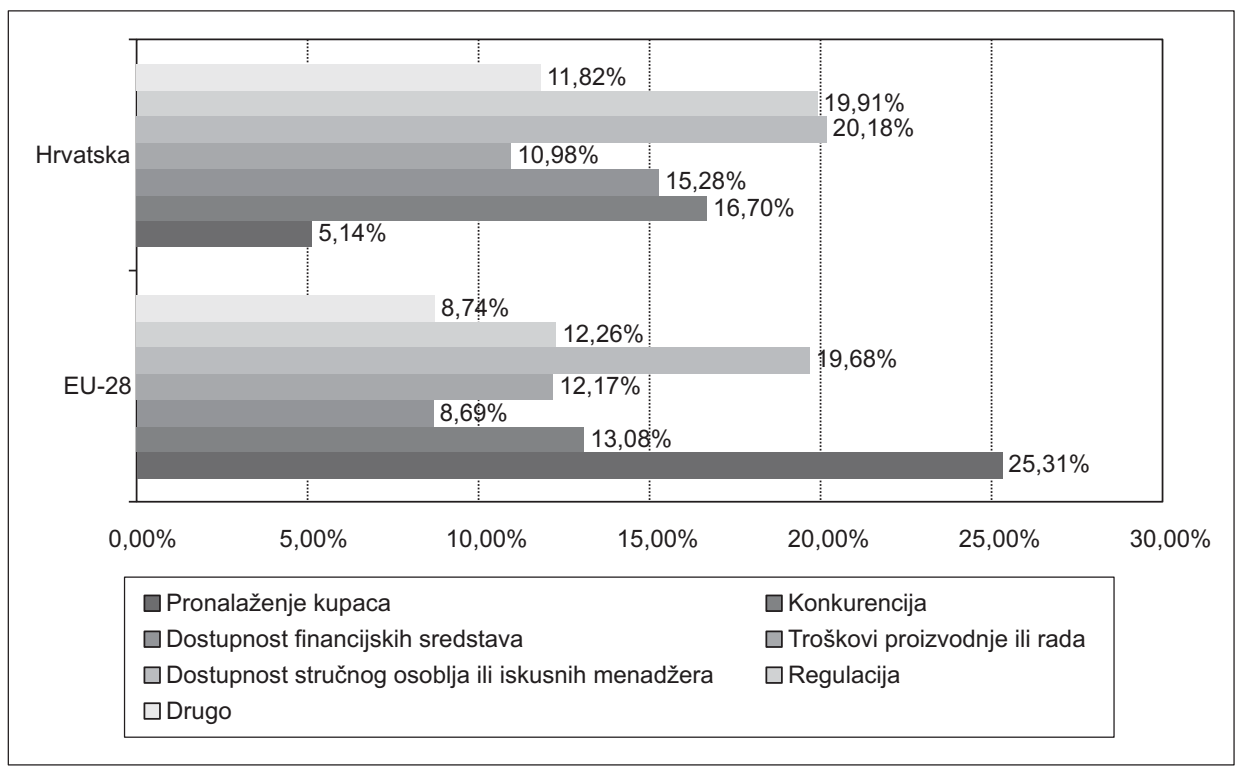

Izvor: European Commission (2016.b.). 
Prosječno mala i srednja poduzeća na području EU-28 u 2016. godini kao najveći problem ističu pronalaženje kupaca za svoje proizvode ili usluge, dok je u Hrvatskoj dostupnost stručnog osoblja ili iskusnih menadžera te regulacija najveći problem. Ukoliko se promatraju pojedine europske zemlje, postoje značajna odstupanja od prosjeka EU-28. Konkurencija je mnogo veći problem u malim i srednjim poduzećima u Finskoj i Malti (u 27\% slučajeva), dok je u Njemačkoj taj problem ocijenjen relativno nisko (8\%). Pristup financiranju je vrlo visok problem malim i srednjim poduzećima u Grčkoj i Ciparu (svugdje u 24\% slučajeva), a najmanje u Ujedinjenom Kraljevstvu, Njemačkoj, Luksemburgu i Estoniji (6\%). Trošak rada i proizvodnje je važno pitanje u Italiji (19\%) i relativno malo na Malti, Cipru i Grčkoj (7\%), dok je dostupnost stručnog osoblja ili iskusnih menadžera relativno je veliki problem u Slovačkoj i Češkoj Republici (obje 31\%). Regulacija predstavlja najveći problem malim i srednjim poduzećima u Hrvatskoj i Francuskoj (u 20\% slučajeva), (European Commission, 2016.b) pri čemu u Hrvatskoj veliki problem predstavljaju krutosti u administrativnim preprekama na tržištu rada.

\subsection{Prepreke i krutosti na tržištu rada}

Stvaranje novih radnih mjesta u malim i srednjim poduzećima nije nikada otežano ili potaknuto samo jednim faktorom. Početkom 2016. godine agencija EU, Eurofound je objavila istraživanje o skupini različitih prepreka prilikom kreiranja radnih mjesta s kojima se suočavaju mala i srednja poduzeća na području EU-28. Zaključeno je kako prepreke mogu biti vanjske i unutarnje (Eurofound, 2016.). Vanjske prepreke, uključuju administrativno i institucionalno poslovno okruženje (npr. reguliranje radnog vremena trgovina, strogi radni zakon), postojeću makroekonomsku situaciju (i rezultirajući pad potražnje, povećanje kašnjenja u plaćanjima i otežavajući pristup financijama), konkurenciju od strane većih ili multinacionalnih poduzeća i sive ekonomije, te visoke troškove rada, koji su povezani s niskom dostupnošću kvalificirane radne snage. Unutarnje prepreke uključuju ekonomski učinak malih i srednjih poduzeća, nedostatak strateškog planiranja, nisku sposobnost internacionalizacije i inovativnosti, neefikasnu organizacijsku strukturu i sposobnost upravljanja, nesposobnost za privlačenje radnika, kao i nisku motivaciju i negativan stav vlasnika ili menadžera (Eurofound, 2016.).

Pravila na tržištu rada mogu imati značajne efekte za ukupnu ekonomsku aktivnost neke nacionalne ekonomije. Podaci Svjetske banke, objavljeni u izvještaju Doing Business (2017.), pokazuju da je kruto reguliranje zapošljavanja povezano s višim razinama neformalnosti, dok blaga pravila na tržištu rada mogu dovesti do diskriminacije i lošeg postupanja prema zaposlenicima (World Bank Group, 2017., str. 87). Spomenuti izvještaj mjeri nekoliko aspekata pravila na tržištu rada: 
zapošljavanje, radno vrijeme, pravila otpuštanja i njihove troškove za 190 zemalja svijeta (World Bank Group, 2017., str. 87). Prema tim podacima, može se zaključiti da ekonomije s fleksibilnijim propisima na tržištu rada imaju veći udio u formalno registriranim poduzećima, te veći udio osiguranika mirovinskog osiguranja, koji može poslužiti kao zamjenska varijabla za službenu zaposlenost (World Bank Group, 2017., str. 87).

Danas je vladama izazov izbjegavanje velikog broja propisa i prekomjerne regulacije, $s$ jedne strane, i uravnoteživanje fleksibilnosti rada uz sigurnost i zaštitu radnika, s druge strane (World Bank, 2012.). Zakonska zaštita zaposlenja (engl. employment protection legislation, EPL) kao skup pravila koja reguliraju zapošljavanje i otpuštanje radnika, je osmišljena kako bi unaprijedila blagostanje radnika i spriječila diskriminaciju (World Bank, 2017., str. 87). Prosječno, poduzeća u neformalnom sektoru imaju manje dodane vrijednosti po radniku i isplaćuju niže plaće od poduzeća u formalnom sektoru (World Bank, 2017., str. 87).

Postojeća ekonomska literatura (OECD, 2010.; Napier et al., 2012.; Criscuolo et al., 2014.) ističe administrativno i institucionalno poslovno okruženje odlučujućim faktorom u kreiranju radnih mjesta u malim i srednjim poduzećima u svim zemljama članicama EU. Na primjer, u Švedskoj gotovo $40 \%$ poduzetnika smatra kako su administrativne prepreke i zakonska regulativa najveća prepreka poslovnom razvoju i rastu (Eurofound, 2016., str. 40). U Estoniji, 38\% malih i srednjih poduzeća ističe otežavajuće zakonodavstvo i pretjeranu birokraciju kao problem, dok u Njemačkoj jedna petina poduzeća smatra kako su nepotrebne birokratske procedure (engl. red tape) vezane uz standarde zaštite okoliša, oporezivanje i radno ili socijalno pravo snažno porasle tijekom posljednjih pet godina (Eurofound, 2016., str. 41). Kvaliteta javnih institucija također utječe na razinu zaposlenosti u malim i srednjim poduzećima. Posebni čimbenici u ovom smislu uključuju razinu transparentnosti javne uprave te njezinu provedbu kontrola i sankcija, učinkovitost i dužinu trajanja donošenja odluka javnih tijela, kao i korupciju što se posebno ističe u slučaju Hrvatske i Italije (Eurofound, 2016., str. 41). Neravnopravna slika poduzetništva, uključujući stigmatizaciju neuspjeha i nevoljkost davanja „druge prilike“, predstavlja zapreku u stvaranju novih radnih mjesta u malim i srednjim poduzećima. Nepovoljna percepcija poduzetništva i osobito malih i srednjih poduzeća negativno utječe na potencijalni broj novo osnovanih poduzeća koja bi kasnije mogla stvarati radna mjesta (Eurofound, 2016., str. 42).

Na vrhu problema koji su sami izazvani brojnim drugim ograničenjima, poput složenosti i nerazumljivosti velikog broja različitih propisa o tržištu rada zasigurno usporavaju rast i stvaranje radnih mjesta, ne samo u Njemačkoj nego i na međunarodnoj razini (Pierre i Scarpetta, 2004.). Gauthier i Gerzovits (1997.) sugeriraju da postoji manje srednjih poduzeća jer se suočavaju s najvišim poreznim stopama i troškovima rada budući da mala poduzeća mogu odabrati da ostanu 
neformalna kako bi izbjegla plaćanje poreza, a veća poduzeća nastoje lobirati za poseban tretman.

Dizajn i sadržaj zakonske regulative nisu jedini činitelji koji otežavaju kreiranje novih poslova u malim i srednjim poduzećima. Problem predstavlja i njihova stabilnost. Česte promjene zakonske regulative su vrlo izazovne za mala i srednja poduzeća i nažalost mogu imati negativan utjecaj na stvaranje novih radnih mjesta. Na primjer, u Hrvatskoj je od 2006. godine uvedeno i izmijenjeno oko 500 propisa, koje poduzeća trebaju kontinuirano pratiti i prilagođavati im se, dok je u Litvi 58\% malih i srednjih poduzeća identificiralo nestabilne i proturječne zakone kao glavnu prepreku njihovom poslovnom razvoju i stvaranju zaposlenosti (Eurofound, 2016., str. 43).

Hrvatsko tržište rada, kao i u slučaju većine ostalih članica EU, karakteriziraju relativno visoke ,krutosti na tržištu rada“. One se prije svega odnose na komplicirane i skupe postupke zapošljavanja i otpuštanja radnika, previsoke minimalne nadnice, previsoke naknade za nezaposlene, previsoku zaštitu radnika, preveliku moć sindikata i dr. Navedeno potvrđuju i podaci Svjetske banke putem kojih je istražena razina rigidnosti na tržištu rada Hrvatske s kojom se susreću mala i srednja poduzeća. Koristile su se četiri mjere regulacije tržišta rada na temelju baze podataka Svjetske banke Doing Business. U navedenoj bazi prikupljaju se podaci o četiri aspekta regulacije tržišta rada: zapošljavanje, radno vrijeme, pravila i trošak otpuštanja. Četiri mjere regulacije tržišta rada u Hrvatskoj prikazane su u Tablici 3.

U usporedbi s drugim zemljama EU, Hrvatska još uvijek ima relativno strogo tržište rada što predstavlja veliku prepreku u razvoju malih i srednjih poduzeća. Ograničenja postoje u administrativnim pravilima zapošljavanja i otpuštanja (Obadić, et al., 2017.). Što se tiče procedure zapošljavanja, Hrvatska još uvijek ima ugovore na određeno vrijeme zabranjene za trajne poslove, relativno visoku propisanu minimalnu nadnicu i ograničenja za noćni rad i godišnji odmor. Uzimajući u obzir pravila i troškove otpuštanja radnika, država u Hrvatskoj zahtijeva obavještavanje treće strane o otkazu i predviđa posebna pravila o otpuštanju tj. prekidu radnog odnosa i ponovnom zapošljavanju. Naknada za otpuštanje iznosi 7,2 tjedana plaće, dok na primjer istovremeno u Austriji, Belgiji, Češkoj, Danskoj, Rumunjskoj, Slovačkoj i Švedskoj ona ne postoji (Svjetska banka, 2017.).

Istraživanje u ovom radu usmjereno je na utvrđivanje vanjskih prepreka prilikom kreiranja radnih mjesta i to na one koje su usmjerene na administrativno i institucionalno okruženje poslovanja malih i srednjih poduzeća. Kako bi se procijenilo postojeće stanje radnih propisa o različitim individualnim karakteristikama malih i srednjih poduzeća s obzirom na administrativne prepreke u procesu zapošljavanja i otpuštanja u Hrvatskoj, te ispitalo istraživačko pitanje, provedeno je primarno istraživanje. 
Tablica 3 .

INDIKATORI REGULACIJE TRŽIŠTA RADA U HRVATSKOJ

\begin{tabular}{|c|c|c|c|c|c|c|c|}
\hline \multicolumn{2}{|c|}{ 1) Zapošljavanje } & \multicolumn{2}{|c|}{ 2) Sati rada } & \multicolumn{2}{|c|}{ 3) Pravila otpuštanja } & \multicolumn{2}{|c|}{$\begin{array}{l}\text { 4) Trošak } \\
\text { otpuštanja }\end{array}$} \\
\hline \multirow{2}{*}{$\begin{array}{l}\text { Ugovori na } \\
\text { određeno } \\
\text { vrijeme } \\
\text { zabranjeni } \\
\text { za trajne } \\
\text { poslove? }\end{array}$} & \multirow[b]{2}{*}{$\mathrm{Da}$} & $\begin{array}{c}\text { Maksimalan broj } \\
\text { radnih dana po } \\
\text { tjednu }\end{array}$ & 6 & $\begin{array}{c}\text { Maksimalno trajanje } \\
\text { probnog razdoblja } \\
\text { (mjeseci) }\end{array}$ & 6 & \multirow{5}{*}{$\begin{array}{l}\text { Otkazni } \\
\text { rok za } \\
\text { otpuštanje } \\
\text { viška } \\
\text { radnika } \\
\text { (tjedana } \\
\text { plaće) }\end{array}$} & \multirow{5}{*}{7.9} \\
\hline & & $\begin{array}{l}\text { Naknada za } \\
\text { noćni rad (\% } \\
\text { plaće po satu) }\end{array}$ & 10 & $\begin{array}{c}\text { Otpuštanja zbog } \\
\text { viška radnika } \\
\text { dopuštena } \\
\text { zakonom? }\end{array}$ & $\mathrm{Da}$ & & \\
\hline \multirow{2}{*}{$\begin{array}{l}\text { Maksimalno } \\
\text { trajanje } \\
\text { ugovora na } \\
\text { određeno } \\
\text { (mjeseci) }\end{array}$} & \multirow{2}{*}{$\begin{array}{c}\text { Nema } \\
\text { ograničenja }\end{array}$} & $\begin{array}{l}\text { Naknada za rad } \\
\text { na dan tjednog } \\
\text { odmora (\% plaće } \\
\text { po satu) }\end{array}$ & 35 & $\begin{array}{l}\text { Obavijest treće } \\
\text { strane ako je jedan } \\
\text { radnik otpušten? }\end{array}$ & $\mathrm{Da}$ & & \\
\hline & & $\begin{array}{l}\text { Naknada za } \\
\text { prekovremeni } \\
\text { rad (\% place po } \\
\text { satu) }\end{array}$ & 50 & $\begin{array}{l}\text { Odobrenje treće } \\
\text { strane ako je jedan } \\
\text { radnik otpušten? }\end{array}$ & $\mathrm{Ne}$ & & \\
\hline \multirow{3}{*}{$\begin{array}{l}\text { Minimalna } \\
\text { nadnica za } \\
\text { radnike na } \\
\text { puno radno } \\
\text { vrijeme (US\$/ } \\
\text { mjesec) }\end{array}$} & \multirow{3}{*}{503.96} & $\begin{array}{l}\text { Ograničenja za } \\
\text { noćni rad? }\end{array}$ & $\mathrm{Da}$ & $\begin{array}{c}\text { Obavijest treće } \\
\text { strane ako je devet } \\
\text { radnika otpušteno? }\end{array}$ & $\mathrm{Da}$ & & \\
\hline & & $\begin{array}{c}\text { Ženama koje } \\
\text { nisu trudne i } \\
\text { nemaju djecu } \\
\text { dopušten je } \\
\text { jednak broj sati } \\
\text { rada noću kao } \\
\text { muškarcima? }\end{array}$ & $\mathrm{Da}$ & $\begin{array}{l}\text { Odobrenje treće } \\
\text { strane ako je devet } \\
\text { radnika otpušteno? }\end{array}$ & $\mathrm{Ne}$ & \multirow{4}{*}{$\begin{array}{l}\text { Otpremnina } \\
\text { za } \\
\text { otpuštanje } \\
\text { viška } \\
\text { radnika } \\
\text { (tjedana } \\
\text { plaće) }\end{array}$} & \\
\hline & & $\begin{array}{c}\text { Ograničenja } \\
\text { za rad na dan } \\
\text { tjednog odmora? }\end{array}$ & $\mathrm{Da}$ & $\begin{array}{c}\text { Prekvalifikacija } \\
\text { ili preraspodjela } \\
\text { obavezna prije } \\
\text { otpuštanja? }\end{array}$ & $\mathrm{Ne}$ & & 7.2 \\
\hline \multirow{2}{*}{$\begin{array}{c}\text { Omjer } \\
\text { minimalne } \\
\text { nadnice } \\
\text { i dodane } \\
\text { vrijednosti po } \\
\text { radniku } \\
\end{array}$} & \multirow{2}{*}{0.32} & $\begin{array}{c}\text { Ograničenja za } \\
\text { prekovremeni } \\
\text { rad? }\end{array}$ & $\mathrm{Ne}$ & $\begin{array}{c}\text { Pravila prioriteta za } \\
\text { otpuštanja? }\end{array}$ & Da & & \\
\hline & & $\begin{array}{l}\text { Plaćen godišnji } \\
\text { odmor (radni } \\
\text { dani) } \\
\end{array}$ & 20.0 & $\begin{array}{c}\text { Pravila prioriteta } \\
\text { za ponovna } \\
\text { zapošljavanja? }\end{array}$ & $\mathrm{Da}$ & & \\
\hline
\end{tabular}

Izvor: Obadić et al. (2017.) prema World Bank Group (2017.) baza podataka Doing Business. 


\section{METODOLOGIJA ISTRAŽIVANJA}

Primarno istraživanje provedeno je u okviru hrvatsko-slovenskog znanstveno-istraživačkog projekta „Djelovanje javne uprave i proceduralna (de) birokratizacija u smislu razvoja malih i srednjih poduzeća: komparativna analiza Slovenije i Hrvatske" za razdoblje 2016.-2017. godine financiranog od strane Ministarstva znanosti i obrazovanja Republike Hrvatske i Ministarstva za izobraževanje, znanost in šport Republike Slovenije. Projekt se provodio s ciljem ocjene trenutnog stanja vezanog za administrativne poslove malih i srednjih poduzeća u nekoliko upravnih područja te ocijene rješenja ili mjera za uklanjanje administrativnih prepreka.

Podaci za ovo istraživanje prikupljeni su pomoću anketnog upitnika. Sadržaj upitnika oblikovali su akademski stručnjaci iz područja ekonomije i prava zajedno s preporukama praktičara, $\mathrm{tj}$. predstavnicima Hrvatske udruge poslodavaca (HUP) i Hrvatske obrtničke komore (HOK). Upitnik sadrži 40 pitanja i obuhvaća različita važna područja u kojima se mala i srednja poduzeća mogu suočiti s administrativnim preprekama, pri čemu je postojala mogućnost neodgovora na pitanja za koja su ispitanici ocijenili da nisu prikladna za njih. Upitnik je distribuiran putem web preglednika svim članovima HUP-a i HOK-a. Kako bi se povećala stopa povrata i reprezentativnost uzorka, upitnik je također podijeljen članovima komore na brojnim sastancima Hrvatske obrtničke komore. On-line anketa se provodila u razdoblju od 5. prosinca 2016. do 31. ožujka 2017. te je rezultirala sa 960 otvorenih anketnih upitnika, od kojih je 734 bilo djelomično ili potpuno ispunjeno. U svrhu analize u ovom radu, u obzir su uzeta samo ona pitanja koja se odnose na područje regulacije tržišta rada. Uzorkom su obuhvaćena poduzeća s područja svih županija RH što znači da je postignuta reprezentativna pokrivenost svih županija u uzorku. Iz uzorka su potom isključena poduzeća koja nisu u potpunosti odgovorila na pitanja koja predstavljaju glavne varijable u analizi, te su isključena velika poduzeća s više od 250 zaposlenika. Konačni uzorak malih i srednjih poduzeća, temeljem kojeg je provedena analiza uključuje 701 poduzeće.

U Tablici 4 prikazana je strukturu uzorka malih i srednjih poduzeća na području svih županija RH. 


\section{Tablica 4.}

\section{STRUKTURA UZORKA PO ŽUPANIJAMA I USPOREDBA S POPULACIJOM MALIH I SREDNJIH PODUZEĆA}

\begin{tabular}{|l|r|r|r|r|}
\hline & \multicolumn{2}{|c|}{ Službeni izvor } & \multicolumn{2}{c|}{ Uzorak } \\
\hline & Broj MSP & MSP(\%) & Broj MSP & MSP(\%) \\
\hline Zagrebačka & 10.707 & $6 \%$ & 90 & $13 \%$ \\
\hline Grad Zagreb & 58.291 & $35 \%$ & 209 & $30 \%$ \\
\hline Krapinsko-zagorska & 2.704 & $2 \%$ & 19 & $3 \%$ \\
\hline Sisačko-moslavačka & 2.653 & $2 \%$ & 14 & $2 \%$ \\
\hline Karlovačka & 2.861 & $2 \%$ & 8 & $1 \%$ \\
\hline Varaždinska & 4.958 & $3 \%$ & 32 & $5 \%$ \\
\hline Koprivničko-križevačka & 2.401 & $1 \%$ & 9 & $1 \%$ \\
\hline Bjelovarsko-bilogorska & 2.593 & $2 \%$ & 18 & $3 \%$ \\
\hline Primorsko-goranska & 14.997 & $9 \%$ & 69 & $10 \%$ \\
\hline Ličko-senjska & 1.090 & $1 \%$ & 7 & $1 \%$ \\
\hline Virovitičko-podravska & 1.330 & $1 \%$ & 13 & $2 \%$ \\
\hline Požeško-slavonska & 1.146 & $1 \%$ & 7 & $1 \%$ \\
\hline Brodsko-posavska & 2.595 & $2 \%$ & 10 & $1 \%$ \\
\hline Zadarska & 5.269 & $3 \%$ & 13 & $2 \%$ \\
\hline Osječko-baranjska & 6.763 & $4 \%$ & 20 & $3 \%$ \\
\hline Šibensko-kninska & 2.966 & $2 \%$ & 15 & $2 \%$ \\
\hline Vukovarsko-srijemska & 2.308 & $1 \%$ & 35 & $5 \%$ \\
\hline Splitsko-dalmatinska & 18.332 & $11 \%$ & 44 & $6 \%$ \\
\hline Istarska & 14.119 & $8 \%$ & 33 & $5 \%$ \\
\hline Dubrovačko-neretvanska & 5.519 & $3 \%$ & 11 & $2 \%$ \\
\hline Međimurska & 4.401 & $3 \%$ & 23 & $3 \%$ \\
\hline Nema odgovora & - & - & 2 & $0 \%$ \\
\hline Ukupno & $\mathbf{1 6 8 . 0 0 3}$ & $\mathbf{1 0 0 \%}$ & $\mathbf{7 0 1}$ & $\mathbf{1 0 0 \%}$ \\
\hline
\end{tabular}

Izvor: izračun autorice na temelju Baze podataka HGK (2016.). Podaci za mikro poduzeća preuzeti su iz Registra poslovnih subjekata - http://wwwl.biznet.hr/HgkWeb/do/extlogon?lang=hr_HR i baze podataka FINA-e (2016.) - Registar godišnjih financijskih izvještaja - http://rgfi.fina.hr/ IzvjestajiRGFI.web/main/home.jsp

Napomena: Kratica MSP se odnosi na mala i srednja poduzeća. 
Najveći broj malih i srednjih poduzeća uključen u analizu nalazi se na području Grada Zagreba (30\%). To je u skladu sa službeno najvećim udjelom registriranih malih i srednjih poduzeća upravo u toj županiji (35\%). I udjeli ostalih županija u uzorku odgovaraju službenoj strukturi poduzeća čitave populacije u RH. Najveće odstupanje zabilježeno je za Splitsko-dalmatinsku županiju, sa proporcionalno najmanjim udjelom anketiranih poduzeća, što se može objasniti činjenicom na vremenski tijek provođenja anketiranja. Naime, anketiranje se provodilo od prosinca do ožujka, kada veći dio malih i srednjih poduzeća na području te županije nije aktivan. Većina poduzeća uključena u istraživanje, pripada skupini mikro poduzeća s manje od 10 zaposlenih (75,5\%), malih je 18,8\% dok srednja čine $5,7 \%$.

Za potrebe ovog empirijskog istraživanja, mala i srednja poduzeća su podijeljena prema tri kriterija: veličina poduzeća (prema broju zaposlenih), pravno-organizacijski oblik i sektor. S obzirom na veličinu poduzeća, mala i srednja poduzeća su podijeljena na mikro poduzeća (s manje od 10 zaposlenih), mala poduzeća (s 10-49 zaposlenih) i srednje velika poduzeća (s 50-249 zaposlenih). Uzimajući u obzir pravno-organizacijski oblik, podijeljena su u društva sa ograničenom odgovornošću, obrtnike i ostala poduzeća. Konačno, mala i srednja poduzeća su podijeljena prema sektorima na primarni, sekundarni, tercijarni i kvartarni sektor. Takvom podjelom, moguće je identificirati potencijalne razlike između pojedinih individualnih grupa malih i srednjih poduzeća u pogledu ključnih administrativnih prepreka na području zapošljavanja.

U skladu s ranije istaknutim ciljem rada, analizirane su prosječne vrijednosti varijable „Opterećenost poduzeća na području zapošljavanja“ kako bi se odgovorilo na glavno istraživačko pitanje rada postoji li između različitih grupa malih i srednjih poduzeća (s obzirom na broj zaposlenih, pravno-organizacijski oblik i sektor) značajna razlika u broju ključnih administrativnih prepreka na području zapošljavanja? Glavna varijabla analize je „,broj ključnih administrativnih prepreka“ koja nam predstavlja proxy varijablu za ,intenzitet administrativnih prepreka“. U Tablici 5. prikazano je sedam tvrdnji koje se odnose na administrativne prepreke s kojima se suočavaju poslodavci na području zapošljavanja prilikom prijave i odjave zaposlenika (npr. obvezna osiguranja - mirovinsko i zdravstveno osiguranje). 


\section{Tablica 5 .}

\section{OPTEREĆENOST PODUZEĆA NA PODRUČJU ZAPOŠLJAVANJA}

\begin{tabular}{|l|l|}
\hline 1 & Potrebno je previše vremena za provedbu traženih postupaka i drugih formalnosti. \\
\hline 2 & $\begin{array}{l}\text { Potrebno je previše financijskih sredstva potrebnih za provedbu traženih postupaka i } \\
\text { drugih formalnosti. }\end{array}$ \\
\hline 3 & Prečeste izmjene propisa vezanih uz poslovanje. \\
\hline 4 & Broj postupaka i drugih formalnosti u području poslovanja je prevelik. \\
\hline 5 & $\begin{array}{l}\text { Potrebna je dodatna osobna interakcija poduzeća s upravnim tijelima (npr. dodatni } \\
\text { sastanci, višekratni dolasci na šalter, itd.). }\end{array}$ \\
\hline 6 & Potreban je preveliki broj različitih dokumenata. \\
\hline 7 & $\begin{array}{l}\text { Potrebna je dodatna pomoć/usluge vanjskih osoba (npr. korištenje računovodstvenog } \\
\text { servisa, odvjetnika, poreznog savjetnika i sl.). }\end{array}$ \\
\hline
\end{tabular}

Izvor: vlastito istraživanje.

Broj ključnih administrativnih prepreka mjeren je na ljestvici od 0 do $3 \mathrm{~s}$ obzirom da svaka tvrdnja može imati vrijednost 0 ili 1, a svako anketirano poduzeće moglo je izabrati najviše 3 od 7 tvrdnji, koje za njih predstavljaju najveću administrativnu prepreku, te stoga vrijednost 3 predstavlja maksimum. Rezultati istraživanja u ovom radu prikazuju se u dva dijela. U prvom dijelu analize koristi se metode deskriptivne statistike. Izračunane su relativne frekvencije i prosječne vrijednosti, a u drugom dijelu istraživanja provedena je analiza varijance.

\section{Rezultati (istraživanja) i rasprava}

Prvi dio rezultata istraživanja prikazuje (na temelju rezultata iz uzorka) opću sliku mogućih prepreka koja mogu opteretiti poslovanje malih i srednjih poduzeća na području regulacije zapošljavanja, a drugi dio prikazuje prosječnu vrijednost broja ključnih administrativnih prepreka na području zapošljavanja u pojedinoj grupi malih i srednjih poduzeća. Analizira se sedam tvrdnji s kojima se suočavaju poslodavci, a relativne frekvencije njihovih odgovara prikazane su u grafikonu 3. 


\section{Grafikon 3.}

\section{PERCEPCIJA ADMINISTRATIVNIH PREPREKA NA PODRUČJU ZAPOŠLJAVANJA $(N=701)$}

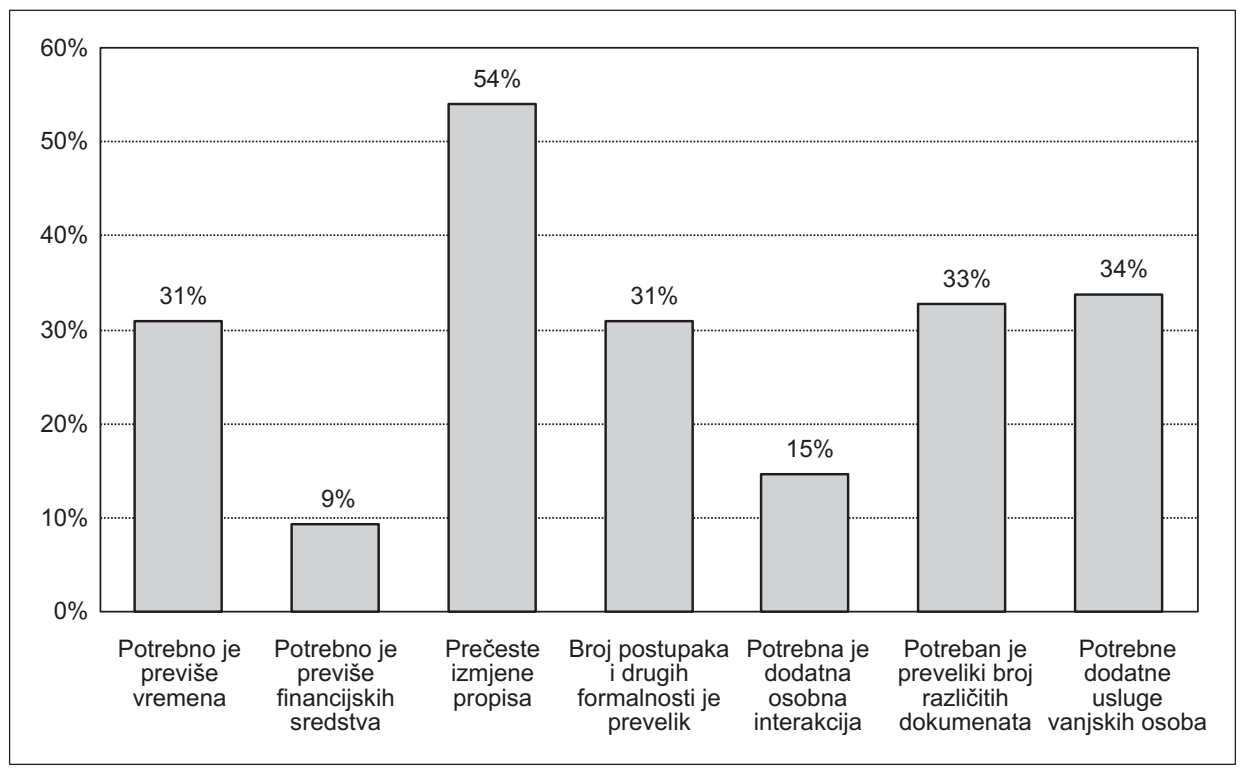

Izvor: vlastito istraživanje.

Na temelju prikazanih podataka jasno je kako većina malih i srednjih poduzeća u uzorku (54\%) najvećom administrativnom preprekom na području regulacije tržišta rada smatra prečeste izmjene propisa vezanih uz poslovanje. Nadalje, više od trećine anketiranih (34\%) ističe kako im je potrebna dodatna pomoć vanjskih osoba za obavljanje administrativnih poslova. Trećina ih (33\%) smatra kako je potreban preveliki broj različitih dokumenata, dok $31 \%$ anketiranih smatra da je potrebno previše vremena za provedbu traženih postupaka te ih isto toliko smatra (31\%) da je broj postupaka i drugih formalnosti u području poslovanja prevelik. Najmanjom preprekom mala i srednja poduzeća smatraju dodatnu osobnu interakciju poduzeća s upravnim tijelima (npr. dodatni sastanci, višekratni dolasci na šalter i dr.) (15\%) te financijska sredstva potrebna za provedbu traženih postupaka i drugih formalnosti (9\%).

Na Grafikonu 4 može se uočiti odgovor na glavno istraživačko pitanje, postoje li, između različitih grupa (a po tri kriterija razvrstavanja poduzeća: veličina poduzeća, pravno-organizacijski oblik i sektor) 701 malog i srednjeg 
poduzeća, razlike u opterećenosti administrativnim poslovima na području zapošljavanja.

\section{Grafikon 4.}

PROSJEČNA VRIJEDNOST BROJA KLJUČNIH ADMINISTRATIVNIH PREPREKA NA PODRUČJU ZAPOŠLJAVANJA U POJEDINOJ GRUPI MALIH I SREDNJIH PODUZEĆA $(N=701)$

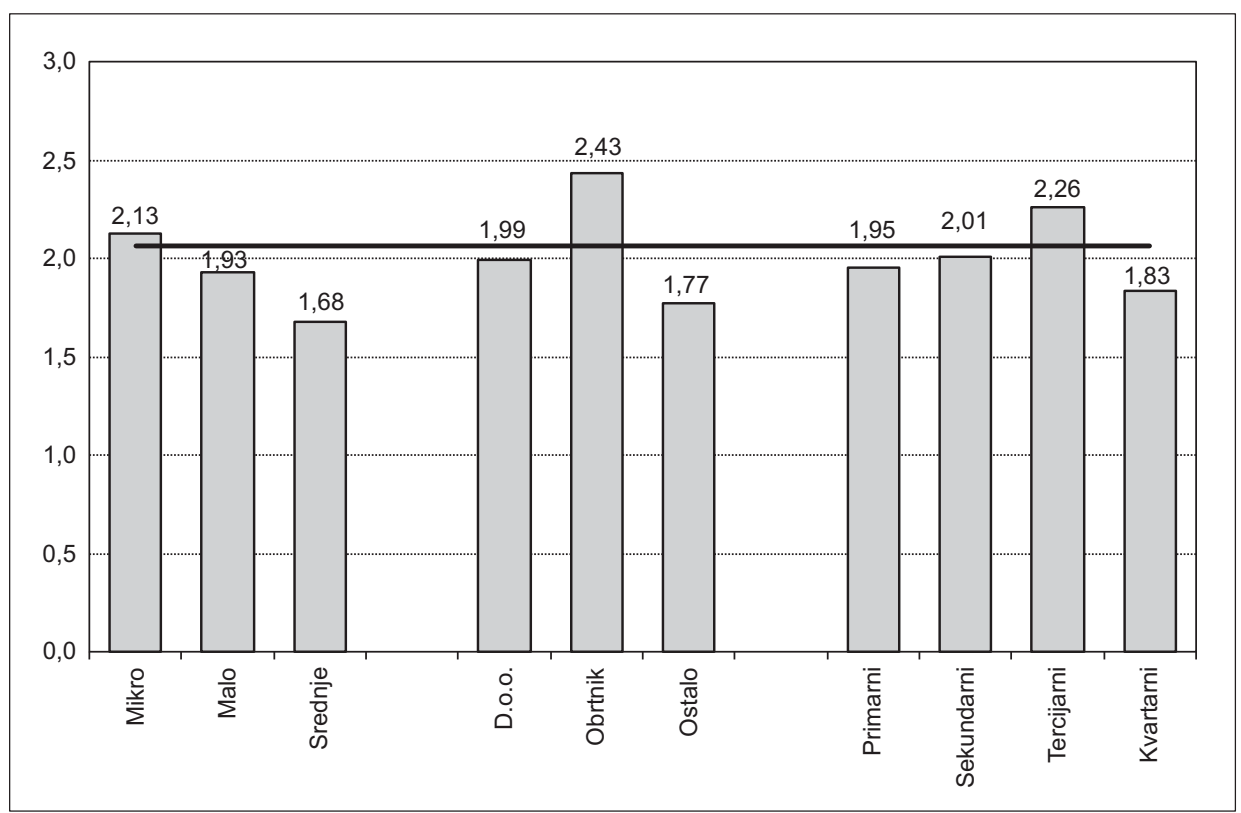

Izvor: vlastito istraživanje.

Uzimajući u obzir prosječnu vrijednost administrativnih prepreka na području regulacije tržišta rada $(2,06)$, na grafikonu 4 uočava se postojanje razlika u percepciji (prosječnoj vrijednosti broja) ključnih administrativnih prepreka na području zapošljavanja između pojedinih grupa malih i srednjih poduzeća. Mikro poduzeća $(2,13)$, obrtnici $(2,43)$ i poduzeća koja djeluju u tercijarnom sektoru $(2,26)$ doživljavaju najviše i iznad prosječno opterećenje administrativnim preprekama u odnosu na prosječnu vrijednost cijelog uzorka, po sva tri kriterija razvrstavanja. Za razliku od njih, srednja poduzeća i poduzeća koja djeluju u kvartarnom sektoru, su najmanje opterećena administrativnim preprekama. Navedeni rezultati potvrđuju da postoje razlike između pojedinih grupa malih i 
srednjih poduzeća, a daljnjom analizom u nastavku povjeriti će se, da li su prikazane razlike značajne.

Drugi dio istraživanja nastoji potvrditi da li se prethodno prikazane percepcije glavne varijable prikazane deskriptivnom analizom, mogu statistički potvrditi i putem analize varijance. Testirane su razlike prosječne vrijednosti varijable „Broj ključnih administrativnih prepreka“, a u Tablici 6 dani su rezultati usporedbu srednjih vrijednosti prema tri kriterija razlikovanja malih i srednjih poduzeća.

Tablica 6.

\section{REZULTATI ANALIZE VARIJANCE O BROJU KLJUČNIH ADMINISTRATIVNIH PREPREKA NA PODRUČJU ZAPOŠLJAVANJA U POJEDINOJ GRUPI MALIH I SREDNJIH PODUZEĆA}

\begin{tabular}{|c|c|c|c|c|}
\hline \multicolumn{2}{|l|}{ Grupa MSP } & $n$ & Prosjek & $p$-vrijednost \\
\hline \multirow{3}{*}{ Broj zaposlenih } & Mikro & 529 & 2,13 & \multirow{3}{*}{$0,036^{*}$} \\
\hline & Malo & 132 & 1,93 & \\
\hline & Srednje & 40 & 1,68 & \\
\hline \multirow{3}{*}{$\begin{array}{c}\text { Pravno-organizacijski } \\
\text { oblik }\end{array}$} & Društvo sa ograničenom odgovornošću & 532 & 1,99 & \multirow{3}{*}{$0,000^{*}$} \\
\hline & Obrtnik & 134 & 2,43 & \\
\hline & Ostalo & 35 & 1,77 & \\
\hline \multirow{4}{*}{ Sektor } & Primarni & 22 & 1,95 & \multirow{4}{*}{$0,001^{*}$} \\
\hline & Sekundarni & 152 & 2,01 & \\
\hline & Tercijarni & 309 & 2,26 & \\
\hline & Kvartarni & 218 & 1,83 & \\
\hline
\end{tabular}

Izvor: vlastito istraživanje.

Napomena: * rezultati su značajni na razini signifikantnosti od 0,05. Kratica MSP se odnosi na mala i srednja poduzeća.

Promotre li se rezultati analize varijance, prezentirani u Tablici 6 može se uočiti da se potvrđuju statistički značajne razlike između različitih grupa malih i srednjih poduzeća u pogledu broja ključnih administrativnih prepreka na području zapošljavanja. Na temelju rezultata provedenog istraživanja, potvrđuje se hipoteza rada, da između različitih grupa malih i srednjih poduzeća (s obzirom na broj zaposlenih, pravno-organizacijski oblik i sektor) postoje razlike u broju ključnih administrativnih prepreka na području zapošljavanja.

S obzirom na broj zaposlenih, najveći broj ključnih administrativnih prepreka na području zapošljavanja percipiraju mikro poduzeća $(2,13)$, a najmanji broj 
srednja poduzeća $(1,68)$. Empirijska razina signifikantnosti (p-vrijednosti) manja je od teorijske razine signifikantnosti 5\%. Stoga se zaključuje da se srednje vrijednosti statistički značajno razlikuju (za tri vrste poduzeća: mikro, mala i srednja) odnosno da postoji barem jedna srednja vrijednost (aritmetička sredina) koja je različita od zajedničke (konstantne) srednje vrijednosti. U slučaju pravno-organizacijskog oblika poduzeća, najveći broj ključnih administrativnih prepreka percipiraju obrtnici $(2,43)$, a najmanji broj sva ostala poduzeća (npr. dioničko društvo (d.d.), komanditno društvo (k.d.), javno trgovačko društvo, gospodarsko interesno udruženje, trgovac pojedinac i ostala) (1,77). Zaključak statističkog testa je isti kao i ranije navedeni. Osim toga, prezentirani rezultati upućuju na zaključak, da poduzeća, koja imaju u prosjeku manji broj zaposlenika, doživljavaju administrativne prepreke na području zapošljavanja intenzivnije nego poduzeća sa većim brojem zaposlenika. Dobivene percepcije su u skladu sa prethodno spomenutim studijama koje pokazuju kako se poduzeća sa manje od deset zaposlenika moraju suočiti sa regulatornim opterećenjem koje je gotovo dvostruko veće od poduzeća koje ima više od 10, a manje od 20 zaposlenika. Razlog za ovaj rezultat je činjenica, da se poduzeća s manjim brojem zaposlenika ne bave s administrativnim aktivnostima na području zapošljavanja na svakodnevnoj razini, pa stoga doživljavaju postojeće administrativne prepreke s većim intenzitetom odnosno kao veće opterećenje. Navedeno je posljedica nedostatka relevantnih znanja zaposlenika.

S obzirom na sektorsku strukturu malih i srednjih poduzeća, najveći broj ključnih administrativnih prepreka percipiraju poduzeća u tercijarnom sektoru $(2,26)$, a najmanji broj ona koja većinom djeluju u kvartarnom sektoru $(1,83)$. I u ovom slučaju je empirijska razina signifikantnosti (p-vrijednosti) manja je od teorijske razine signifikantnosti 5\% što znači da se navedene četiri srednje vrijednosti statistički značajno razlikuju. Naime, tercijarni sektor uključuje uglavnom uslužne djelatnosti koje se bave ispunjavanjem obaveza prema javnoj upravi za druga poduzeća (npr. računovodstveni servis, odvjetnik, porezni savjetnik). Ovakvi rezultati upućuju, da ispitanici koji rade u poduzećima na području tercijarnog sektora doživljavaju administrativne prepreke na području zapošljavanja s većim intenzitetom što je posljedica prekomjernog opsega posla uzrokovanog administrativnim preprekama na području zapošljavanja, u odnosu na poduzeća koja se nalaze u drugim sektorima.

\section{Zaključak}

Obzirom na novo ostvarenu dodanu vrijednost i ukupno zapošljavanje mala i srednja poduzeća imaju ključnu ulogu u europskom gospodarstvu. Neupitno je kako se ona susreću s mnogo većim administrativnim poteškoćama u svojem poslovanju u usporedbi s velikim poduzećima. Brojne rigidnosti na tržištu rada još 
više otežavaju već ionako prisutne prepreke s kojima se suočavaju mala i srednja poduzeća prilikom kreiranja radnih mjesta. Stoga je cilj rada bio istražiti i ocijeniti trenutno stanje vezano uz administrativne prepreke malih i srednjih poduzeća na području regulacije tržišta rada u EU-28 i Hrvatskoj. U usporedbi s drugim zemljama EU, Hrvatska u pogledu procedure zapošljavanja, pokazuje relativno rigidno tržište rada što predstavlja veliku prepreku u razvoju malih i srednjih poduzeća. Hrvatska još uvijek ima ugovore na određeno vrijeme zabranjene za trajne poslove, relativno visoku propisanu minimalnu nadnicu i ograničenja za noćni rad i godišnji odmor, a država od poslodavaca zahtijeva obavještavanje treće strane o otkazu i predviđa posebna pravila o otpuštanju tj. prekidu radnog odnosa i ponovnom zapošljavanju.

Kod interpretacije rezultata primarnog istraživanja provedenog u ovom radu, treba uzeti u obzir i postojeća ograničenja, koja proizlaze iz vrste on-line istraživanja, a povezana su s nesigurnosti u pravi identitet sudionika i odustajanjem od ispunjavanja ankete prije kraja. Također, treba imati u vidu da možda ipak sva mala i srednja poduzeća, članovi HGK-a i HOK-a, nisu korisnici Interneta. Unatoč navedenom postignuta je reprezentativna pokrivenost svih županija u uzorku. Rezultati potvrđuju da postoje statistički značajne razlike između različitih grupa malih i srednjih poduzeća u pogledu broja ključnih administrativnih prepreka na području zapošljavanja. Tako najveći broj administrativnih prepreka na području zapošljavanja percipiraju mikro poduzeća i obrtnici koji razvijaju svoju djelatnost u području tercijarnog sektora. Navedeni rezultati su prije svega korisni regulatornim tijelima, prilikom pripremanja i oblikovanja nove zakonske regulative na području zapošljavanja. Naime, rezultati istraživanja jasno ukazuju da među različitim grupama malih i srednjih poduzeća postoje ranjive skupine, koje se na različite načine suočavaju sa administrativnim preprekama te ih stoga percipiraju na različite načine.

\section{Literatura:}

Aristovnik, A., Obadić, A. (2015.). „The Impact and Efficiency of Public Administration Excellence on Fostering SMEs in EU Countries“, Amfiteatru Economic, 17 (39), May 2015, Bucharest University of Economic Studies, Romania Faculty of Business and Tourism; Editura ASE, Bucuresti, Romania: 761-774.

CEPOR (2017.). Small and Medium Enterprises Report Croatia - 2016., including the results of GEM - Global Entrepreneurship Monitor research for Croatia for 2015, Zagreb, May 2017.

Criscuolo, C., Gal, P. N., Menon, C. (2014.). The dynamics of employment growth: New evidence from 18 countries, OECD Science, Technology and Industry Policy Papres No. 14, OECD Publishing, Paris. 
Eurofound (2016.). Job creation in SMEs: ERM annual report 2015, Publications Office of the European Union, Luxembourg.

European Central Bank (2017.). Survey on the access to finance of enterprises (SAFE), different Reports, On line at: https://www.ecb.europa.eu/stats/ecb_surveys/safe/ html/index.en.html

European Commission (2003.). Commission Recommendation of 6 May 2003 concerning the definition of micro, small and medium-sized enterprises (2003/361/EC); Official Journal of the European Union, L 124/36, 20.05.2003.

European Commission (2005.). Communication from the Commission to the Council and the European Parliament - Better Regulation for Growth and Jobs in the European Union, COM (2005) 97final, On line at: http://ec.europa.eu/environment/sme/index_en.htm.

European Commission (2007.). Action programme for reducing administrative burdens in the European Union. COM(2007) 23 final, Brussels.

European Commission (2014.). Public administration scoreboard, http://www. google.hr/url?sa=t\&rct=j\&q=\&esrc=s\&source=web\&cd=2\&ved=0ahUKEwiF 1LSq8_rLAhWFDA8KHTeLDicQFggjMAE\&url=http\%3A\%2F\%2Fec.europa. eu\%2FDocsRoom $\% 2$ Fdocuments $\% 2$ F7162\%2Fattachments $\% 2$ F1\%2Ftranslatio ns $\% 2 F e n \% 2 F r e n d i t i o n s \% 2 F n a t i v e \& u s g=A F Q j C N G i E R c O F w n o g F v 1 i j 5 R R v$ hownXKA\&bvm=bv.118443451,bs.1,d.bGg (pristupljeno, 20. listopada, 2017.)

European Commission (2016a.). Annual Report on European SMEs 2015/2016 - SME recovery continues, SME Performance Review 2015/2016, Final Report, November 2016. DOI 10.2873/76227.

European Commission (2016b.). Survey on the access to finance of enterprises (SAFE) Analytical Report 2016, Luxembourg: Publications Office of the European Union, November 2016. doi: 10.2873/435315

European Parliament (2017.). Small and Medium-sized Enterprise; Fact Sheets on the European Union, 06/2017.

FINA (2016.). Registar godišnjih financijskih izvještaja, Financijska agencija, Zagreb http://rgfi.fina.hr/IzvjestajiRGFI.web/main/home.jsp (pristupljeno, 30. travnja, 2016.)

Gaëlle, P., Scarpetto, S. (2004.). „Employment regulations through the eyes of employers: do they matter and how do firms respond to them“, IZA Discussion Paper, No. 1424, December 2004: 1-44. http://ftp.iza.org/dp1424.pdf

Gauthier, B., Gerzovits, M. (1997.). „Revenue erosion through tax exemption and evasion in poor countries“, Journal of Public Economics, (64), 3: 407-424.

HGK (2016.). Registar poslovnih subjekata, Hrvatska gospodarska komora, Zagreb - http:// wwwl.biznet.hr/HgkWeb/do/extlogon?lang=hr_HR (pristupljeno, 30. ožujka, 2016.)

Hyman, E. L. (1989.). „The role of small- and micro-enterprises in regional development“, Project Appraisal, (4), 4: 197-214. DOI: 10.1080/02688867.1989.9726734

Napier G., Rouvinen P., Johansson D., Finnbjörnsson T., Solberg E., Pedersen K. (2012.). The Nordic growth entrepreurship review 2012, final report, Nordic Innovation Publication 2012: 25, Oslo. 
http://www.nordicinnovation.org/Global/_Publications/Reports/2013/NGER_2012_noApp.pdf

Obadić, A., Aristovnik, A. (2016.). „The Role of Public Administration Performance in improving the Business Environment for SMEs in the EU“, 8th International Conference „An Enterprise Odyssey: Saving the Sinking Ship Through Human Capital" Proceedings, Zagreb, Croatia, June 8-11, str. 460-469.

Obadić, A., Aristovnik, A., Ravšelj, D. (2017.). Analysis of Administrative Barriers for SMEs in the Field of Labour Market Regulation; Proceedings of 5th Annual Spain Business Research Conference, Global Research Institute for Business Academics, Australia; 11-12 September 2017, Barcelona, Španjolska, str. 1-14.

OECD (2000.). Small and Medium-sized Enterprises: Local Strength, Global Reach, Policy Brief, June 2000, p. 1-8.

OECD (2010.). Issues paper 1: Innovative SMEs and entrepreneurship for job creation and growth, Conference paper, „Bologna+10“ High-level meeting on lessons from the global crisis and the way forward to job ceation and growth; OECD Working Party on SMEs and Entrepreneurship (WPSMEE), 17-18 November, Paris.

Rex, A., Oscar, P., ter Hedde, M., van Dijk J. (2014.). „Does e-government reduce the administrative burden of businesses? An assessment of business-to-government systems usage in the Netherlands", Government Information Quarterly, 31: 160-169. http://dx.doi.org/10.1016/j.giq.2013.09.002

Szczepaǹski, M. (2016.). „Barriers to SME growth in Europe“, EPRS/European Parliamentary Research Service, PE 583.788; May 2016.

Szczepaǹski, M. (2017.). „Helping European SMEs to grow - Start-up and scale-up initiatives for business ventures in the E“, In-Depth Analysis, EPRS - European Research Service, June 2017.

UK Cabinet Office (2006.). Administrative burdens - Routes to reduction. London, UK: Better Regulation Executive.

World Bank (2012.). World Development Report 2013: Jobs. Washington, DC: World Bank.

World Bank Group (2017.). Doing Business 2017. Washington DC: World Bank. 


\title{
ADMINISTRATIVE OBSTACLES THAT SMALL AND MEDIUM-SIZED ENTERPRISES ARE FACING IN THE EMPLOYMENT AREA
}

\begin{abstract}
Small and medium-sized enterprises (SMEs) play a key role in the European economy, but at the same time face much greater administrative difficulties in their business compared to large ones. Existing rigidities in the labour market have further hindered their position in creating new jobs. Therefore, the aim of this paper was to explore whether there were significant differences in the administrative burden in the field of employment between the various groups of small and medium-sized enterprises? The results show that Croatia compared to other EU countries is still rich in rigidities and has a relatively inflexible labour market. Primary research provided in Croatia included a final sample of 701 small and medium-sized enterprises. Research results showed that most SMSs (54\%) consider too frequently changes in business regulations as the biggest administrative barrier in the labour market regulation. Based on the conducted research it is concluded that there are significant differences between different groups (number of employees, legal-organizational form and sector) of small and medium-sized enterprises in terms of the number of key administrative barriers to employment, which are most perceived by micro-enterprises and craftsmen who develop their activities in the tertiary sector.
\end{abstract}

Key words: administrative obstacles, small and medium enterprises, labour markets, EU, Croatia 